\title{
Estimation of economic loss and identifying the factors affecting the crop raiding behaviour of Asian elephant (Elephas maximus) in Nilambur part of the southern Western Ghats, Kerala, India
}

\author{
Riju P. Nair ${ }^{1,2, *}$ and E. A. Jayson ${ }^{1}$ \\ ${ }^{1}$ Wildlife Biology Department, Kerala Forest Research Institute, Peechi 680 653, India \\ ${ }^{2}$ University of Calicut, Thenhipalam 673 635, India
}

\begin{abstract}
The crop damage by the Asian elephant (Elephas maximus) on the livelihood of farmers is a major impediment to the conservation of the endangered mammals. The study was carried out in Malappuram district, Kerala, India from January 2013 to May 2016, to estimate the extent of crop damage by Asian elephants and to identify the factors affecting human-elephant conflict. To estimate the monetary loss, the method of running quadrats was employed. The major cashcrops destroyed by the Asian elephant were plantain (Musa paradisiaca), rubber (Hevea brasiliensis), areca nut (Areca catechu) and coconut (Cocos nucifera). A potential loss of Rs 5,076,827 (US\$ 72,948) per annum (Rs 2,217,363 (US\$ 31,861) (other crops) + Rs 2859,464 (US\$ 41,087) (rubber)) was estimated. Fifty per cent of the encounters occurred at early midnight. The presence of areca nut cultivation and distance to the Reserve Forest were identified as the two factors affecting crop raiding. The damage to rubber trees by feeding on the bark has also been reported.
\end{abstract}

Keywords: Areca nut cultivation, Asian elephant, crop damage, potential loss, running quadrats.

ASIAN elephant (Elephas maximus) is categorized as an endangered animal in the IUCN Red List ${ }^{1}$. The large herbivore is adapted to a wide range of habitats from dense forest to grassland ${ }^{2}$. The cultivation of palatable crops in the forest borders leads to increased human-elephant encounters $^{2,3}$. Human-elephant conflict (HEC) is a primary concern for conservation efforts as it evolves a negative attitude among the affected people. Many previous studies focused on explaining the site-specific factors influencing HEC from different parts of the world which are essential for the success of various management strategies ${ }^{4-6}$. Crop damage by the Asian elephant is a grave problem in tropical Asian countries ${ }^{7,8}$. The plantain, rubber and oil palm

\footnotetext{
*For correspondence. (e-mail: rijupnair2009@gmail.com)
}

plantations are vulnerable to crop-raiding elephants in Malaysia ${ }^{7}$. Zhang and $\mathrm{Wang}^{8}$ reported that wheat, rice and corn in the open fields, and maize and plantain on hill slopes are the crops mainly affected by the elephants in Simao, China. A survey conducted around the five protected reserves in the Western Ghats reported Asian elephant as the top-ranked species causing crop loss across all reserves, after wild pig ${ }^{9}$. A loss of Rs 121.18 thousand (US\$ 1.89 thousand) was estimated from crop depredation by Asian elephants in the Manas National Park, Assam, India ${ }^{10}$. Significant economic loss due to crop depredation in the adjoining regions of Bannerghatta National Park (BNP), Karnataka, India was also reported ${ }^{11}$.

Previous studies from Kerala, India, showed that crop damage by the Asian elephant was primarily affecting the livelihood of marginal farmers ${ }^{12-15}$. Asian elephants caused the most significant harm to crops cultivated in the forest borders of Thrissur district, Kerala ${ }^{15}$. The loss due to crop damage by Asian elephants is always a challenge to the conservation efforts as it increases the animosity towards the animals ${ }^{16}$. All these studies suggest the need for more research on the economic aspect of crop loss due the Asian elephant, which is the most practical way to convince the Government authorities to formulate suitable management strategies.

The present study was carried out in the Nilambur Forest Divisions of Malappuram district, Kerala from January 2013 to May 2016. Majority of the forest fringe villagers in Malappuram district expressed fear due to unexpected encounters with elephants ${ }^{17}$. They perceived crop destruction by the elephants as the major issue, followed by injury or death ${ }^{17}$. The study was initiated to estimate the crop damage by Asian elephants in Malappuram district, in which HEC was reported regularly before the study period. The major objectives of the study were to estimate the economic loss to farmers due to the crop-raiding Asian elephants and identify the factors affecting HEC in the district. 


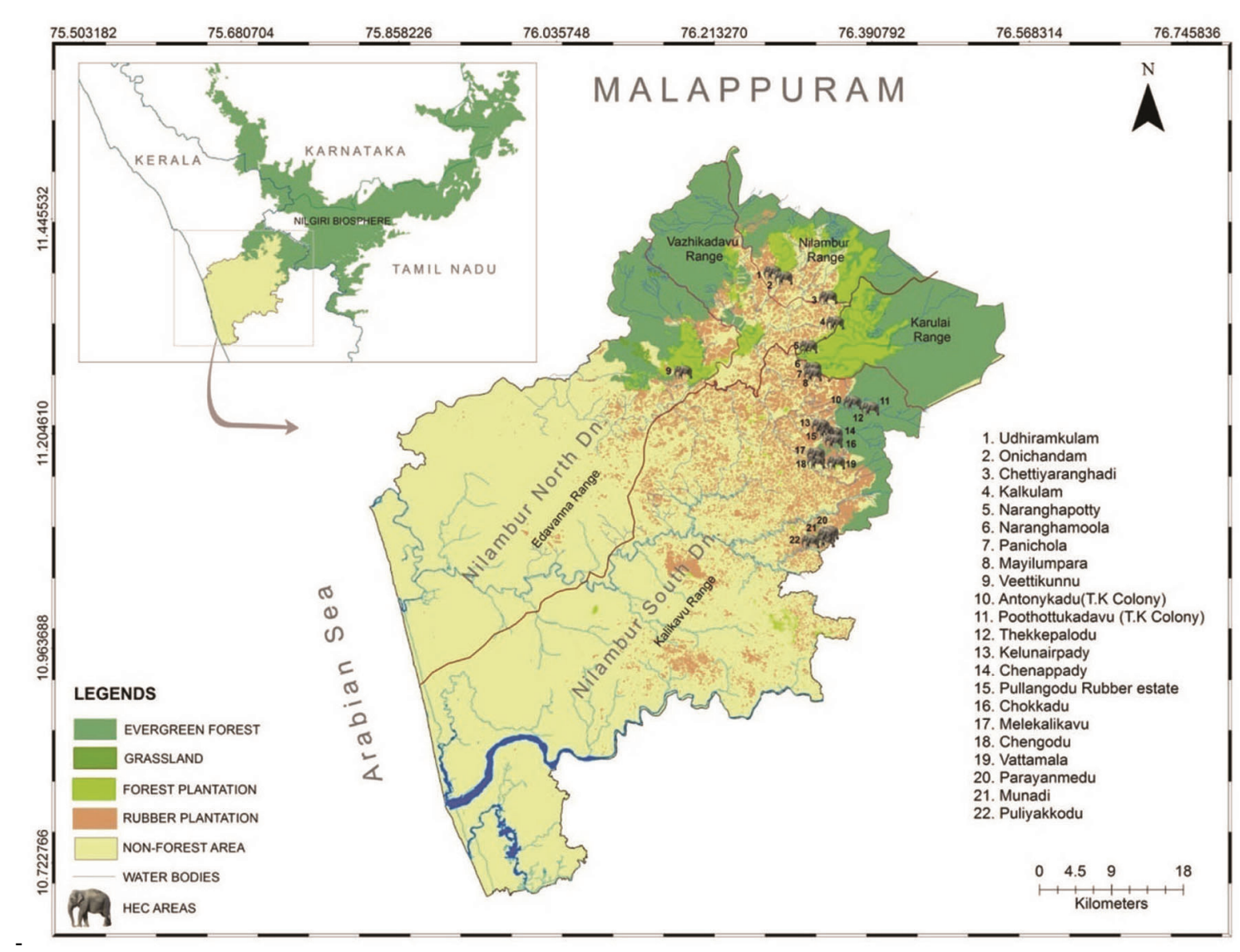

Figure 1. Study area showing locations of damage due to Asian elephants.

\section{Study area}

Malappuram district $\left(10^{\circ} 45^{\prime}-11^{\circ} 25^{\prime} \mathrm{N}\right.$ and $75^{\circ} 55^{\prime}-$ $76^{\circ} 24^{\prime} \mathrm{E}$ ), spanning an area of $3550 \mathrm{sq} . \mathrm{km}$, is situated $50 \mathrm{~km}$ southeast of Kozhikode, bounded by the Nilgiri Hills in the east, Arabian Sea in the west, Thrissur and Palakkad districts in the south and Wayanad district in the north (Figure 1). The main crop species include paddy (Oryza sativa), plantain (Musa paradisiaca), areca nut (Areca catechu), cashew nut (Anacardium occidentale), coconut (Cocos nucifera), rubber (Hevea brasiliensis), pepper (Piper nigrum) and tapioca (Manihot esculenta). Malappuram district comprises of three forest ranges, namely Edavanna, Nilambur and Vazhikadavu of Nilambur North Forest Division and two forest ranges, namely Kalikavu and Karulai of Nilambur South Forest Division. The district has $1034.2 \mathrm{sq}$. $\mathrm{km}$ under forest with all the seven forest types of southern India, tropical moist deciduous, viz. tropical evergreen, tropical semi-evergreen, subtropical hills forest, sub-tropical savannahs, montane wet temperate forests and montane grasslands apart from these teak plantations raised in the Reserve Forest $^{18}$. Asian elephant, wild pig (Sus scrofa), leopard (Panthera pardus), Indian crested porcupine (Hystrix indica) and bonnet macaque (Macaca radiata) are the wild mammal species known from the area.
The climate is tropical with the maximum temperature ranging from $28.90^{\circ} \mathrm{C}$ to $36.20^{\circ} \mathrm{C}$ and minimum temperature from $17.00^{\circ} \mathrm{C}$ to $23.40^{\circ} \mathrm{C}$ (ref. 19).

\section{Materials and methods}

\section{Running quadrats}

The quadrats that were established in the cropland after the Asian elephant encounters occurred were termed as running quadrat. Unlike the permanent quadrats, the number of running quadrats was directly proportional to the area of damaged croplands. To quantify crop damage by Asian elephants in a crop field, running quadrats of $10 \mathrm{~m} \times 10 \mathrm{~m}$ were laid in the damaged croplands ${ }^{20}$. The damage by elephants was confirmed by examining the indirect signs (footprints and dung piles) and mode of consumption (uprooting, trampling and debarking) in the farmlands. The information regarding place, number of damaged and undamaged plants, age of the crops, time of attack, number of elephants and distance from the Reserve Forest was collected by direct observation from the field as well as through the focus group discussions with at least ten people selected from the place of crop damage. A total of 358 (278 (crops other than rubber) +80 (rubber)) running quadrats were laid during 
the study. The mean value of elephant encounters in the crop field was calculated as: number of encounters in each month/3 (number of years) to determine the seasonality of elephant encounters.

\section{Economic loss estimation}

The economic loss was estimated based on the market price of the commodities collected from website of the Farm Information Bureau, Kerala during the study period. The price of commodities in northern Kerala for three days was selected each month, with a gap of 10 days $(n=36)$ (Table 1). The average market price of the commodities was multiplied by the number of crops damaged from the quadrats to calculate monetary loss. The potential loss of perennial crops was estimated by dividing their economic life period into the immature phase and productive phase. The potential value of the crops damaged in the immature phase was equal to the market price of a new plant or seed. If a crop was destroyed during the productive phase, then its potential loss was estimated by multiplying the average market price of the yield during the study period and total yield per tree during its economic life period (Table 2). The perennial crops at the edge of the forest are vulnerable to get damaged by the Asian elephant at any age. So the productive phase was equally divided into two age classes, i.e. primary stage (the period from the initial stage of bearing to the middle age of the productive phase) and secondary stage (the period from the middle age of the productive phase to the end of the economic life period). The overall potential value of the perennial crops was considered if the crops were damaged in the primary stage. If the crops were damaged during the secondary stage, half of the overall potential value was considered. Only the perennial crops with more than $50 \%$ of damage and the species with total damage of more than 20 trees were considered for potential loss estimation. The average yield per annum of the perennial crops was obtained from the Rubber Board Kottayam; Kerala Agricultural University, Thrissur, and Central Plantation Crops Research Institute, Kasaragod in Kerala. The potential economic loss to rubber trees in the district was treated as a particular case. It is considered a rare incident in the study area and has not been reported earlier in India.

Table 1. Market price of different crops

\begin{tabular}{lc}
\hline Cash crops & Market price (Rs) (mean \pm SD) \\
\hline Coconut & $8.096 \pm 1.523$ per nut \\
Areca nut & $139.17 \pm 22.85$ per kg \\
Rubber & $123.883 \pm 25.14$ per kg \\
Banana (Nendra) & $30.694 \pm 7.733$ per kg \\
Banana (Palayamthodan) & $16.32 \pm 3.34$ per kg \\
Plantain (Nendra) & 368.33 per plant \\
Plantain (Palayamthodan) & 326.4 per plant \\
\hline
\end{tabular}

\section{Factors affecting HEC}

To determine the factors affecting HEC, environmental variables of the study area were analysed using binary logistic regression analysis (Table 3 ). Binary logistic regression analysis was used as the selected variables include different crops which can be entered in binary values. The entire study area was divided into grids of $2 \mathrm{~km} \times 2 \mathrm{~km}$ size to ensure the presence of different crop species in maximum grids. The cells with recorded HEC were selected as conflict cells and the non-conflict cells (those without HEC) were selected in the simple random method. In the selected non-conflict cells, four locations from each cell were chosen to extract the numerical value of the required parameters and the mean value was used for analysis. While selecting the non-conflict cells, those in the western part of the district were not considered, as they are far away from the Reserve Forest and the chances of human-elephant interaction are nil. All the independent variables were superimposed onto the grid cells in a manner to cover the elephant range. The entry and exit of environmental variables were determined by Wald statistic with $P$-values of 0.05 and 0.1 respectively. Spearman's rank correlation (rs) was used to determine the relationship between predicted probabilities of the occurrence of crop damage from the logistic model and the HECs in the grid cells ${ }^{4,21}$.

\section{Results}

HECs were encountered in the Nilambur South Forest Division and also in Vazhikadavu and Edavanna ranges of the Nilambur North Forest Division. Cash crops damaged were plantain, coconut, areca nut, rubber, nutmeg (Myristica fragrans) and teak (Tectona grandis). Twenty-two sites ( 830 ha) out of 2685.05 ha of cropland in the district were prone to frequent elephant encounters (Figure 1). A total of 3.58 ha crop area damaged by Asian elephants was recorded from the district (Table 4).

The forest fringe farmers cultivate coconut, areca nut, rubber, plantain, paddy and pineapple. Rubber is the main cash crop sharing most of the forest boundaries in the district. Elephants largely consumed plantain, areca nut, coconut and rubber. Paddy and teak were also destroyed in negligible quantities. HEC was not reported in Nilambur Forest Range, whereas Karulai Forest Range followed by Kalikavu and Vazhikadavu faced severe crop loss (Figure 2).

Forty cases of elephant encounters resulting in crop depredation were recorded. Highest elephant encounters were reported during July and August (Figure 3). Fiftyfive per cent of the total encounters occurred during the southwest monsoon (June-September; $n=40$ ). To substantiate the relationship between the climatic parameters and crop raid, temperature and rainfall of the area were 
RESEARCH ARTICLES

Table 2. Potential value of perennial crops damaged by Asian elephants in Malappuram district, Kerala, India

\begin{tabular}{|c|c|c|c|c|c|c|}
\hline Species & $\begin{array}{l}\text { Economic life } \\
\text { period (years) }\end{array}$ & $\begin{array}{l}\text { Average yield } \\
\text { per annum }\end{array}$ & \multicolumn{2}{|c|}{ Categorization } & $\begin{array}{l}\text { Age class } \\
\text { (years) }\end{array}$ & $\begin{array}{c}\text { Potential } \\
\text { value (Rs) }\end{array}$ \\
\hline \multirow[t]{3}{*}{ Rubber tree } & 32 & $\begin{array}{l}5.5 \mathrm{~kg} \text { of dried } \\
\text { rubber }\end{array}$ & Immature phase & & $0-6$ & 80.00 \\
\hline & & & Productive phase & Primary stage & $7-19$ & $21,803.40$ \\
\hline & & & & Secondary stage & $20-32$ & $10,901.70$ \\
\hline & & & & Secondary stage & $35-60$ & 16,192 \\
\hline \multirow[t]{3}{*}{ Areca nut tree } & 20 & $16 \mathrm{~kg}$ of areca nut & Immature phase & & $0-5$ & 15.00 \\
\hline & & & Productive phase & Primary stage & $6-13$ & $33,400.8$ \\
\hline & & & & Secondary stage & $14-20$ & $16,700.4$ \\
\hline
\end{tabular}

Table 3. Variables selected for binary logistic regression analysis

\begin{tabular}{ll}
\hline Variables & \multicolumn{1}{c}{ Source } \\
\hline Altitude $(\mathrm{m})$ & Measured using GPS \\
Slope (angle) & Recorded from digital elevation model (DEM) \\
Aspect value & Recorded from DEM \\
Canopy density & Calculated by preparing normalized difference vegetation \\
& index (NDVI) map of the study area from Landsat 7 \\
& satellite images using ArcGIS 10 software \\
Distance from the river $(\mathrm{m})$ & Measured from toposheets \\
Distance to the Reserve Forest (RF; $\mathrm{m})$ & Measured from toposheets \\
Areca nut & Recorded from the field \\
Plantain & Recorded from the field \\
Rubber & Recorded from the field \\
Coconut & Recorded from the field \\
\hline
\end{tabular}

Table 4. Crop area damaged by the Asian elephants in Malappuram district $(n=358)$

\begin{tabular}{lc}
\hline Forest ranges & Total crop area damaged (ha) \\
\hline Karulai & 1.93 \\
Kalikavu & 1.05 \\
Vazhikadavu & 0.58 \\
Edavanna & 0.02 \\
Total & 3.58 \\
\hline
\end{tabular}

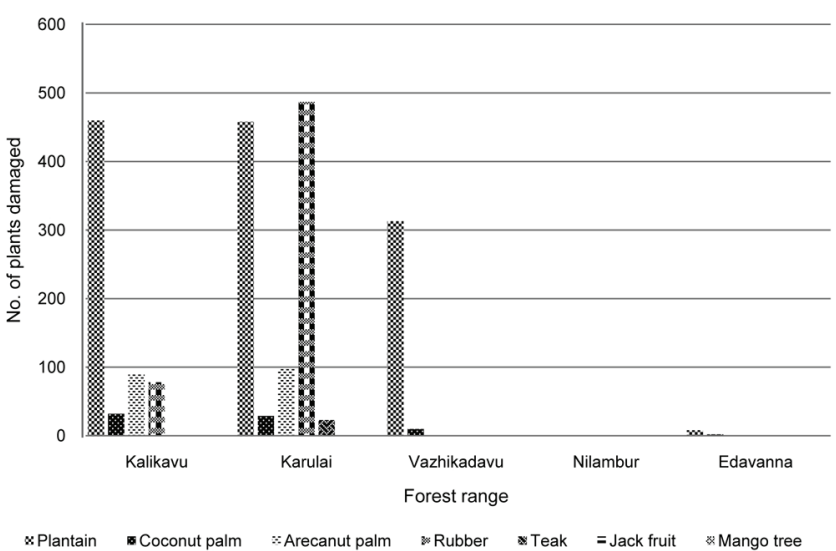

Figure 2. Crop damage recorded from various forest ranges.

correlated with the seasonal encounter of elephants. There was a significant positive correlation with rainfall $(P=0.046$, Pearson's correlation coefficient, $r=0.584)$ and no significant correlation was observed with temperature $(r=0.546, P>0.05)$. The crop raiders intruded into the croplands up to $6 \mathrm{~km}$ from the Reserve Forest through human-inhabited areas; only $30 \%$ of the encounters occurred within $1 \mathrm{~km}$ from the forestland $(n=40)$ (Figure $4)$. Fifty per cent of the encounters occurred at early midnight. The average herd size recorded during crop-raiding was $4.21 \pm 2.79$ elephants and $21 \%$ of the herds were juveniles (from focus group discussions and indirect signs; $n=24)$.

\section{Influence of plantations}

Ten variables were selected for the binary logistic regression. The result showed that areca nut cultivation and distance from the Reserve Forest were the two predictable variables in the model for crop-raiding by Asian elephants (Table 5). The odds of crop damage predicted by the model for the presence of areca nut plantation was 18.717, which in turn, reveals that crop damage was 18.717 times higher in the presence of areca nut plantation $(P<0.05)$. There was only a slight increase $(0.021)$ in HEC for decreased distance to Reserve Forest $(P<0.05)$.

\section{Crops damaged}

The Asian elephants considerably damaged plantain $(59.09 \%)$ followed by rubber $(26.63 \%)$, areca palm 
Table 5. Environmental variables in the logistic regression model $(n=45)$

\begin{tabular}{lcccccc}
\hline Variables & $\begin{array}{c}\text { Regression } \\
\text { coefficients }(\beta)\end{array}$ & $\begin{array}{c}\text { Standard error } \\
(\mathrm{SE})\end{array}$ & $\begin{array}{c}\text { Wald statistic } \\
\left(X^{2}\right)\end{array}$ & $\mathrm{d} f$ & $P$ value & Odds ratio \\
\hline Elevation & 1.139 & 1.123 & 1.029 & 1 & 0.310 & 3.125 \\
Slope & 0.970 & 1.274 & 0.579 & 1 & 0.447 & 2.637 \\
Distance to RF & -3.855 & 1.301 & 8.783 & 1 & 0.003 & 0.021 \\
Areca nut & 2.929 & 1.354 & 4.680 & 1 & 0.031 & 18.717 \\
Rubber & 2.267 & 2.621 & 0.748 & 1 & 0.387 & 9.650 \\
Coconut & 1.106 & 1.240 & 0.796 & 1 & 0.372 & 3.023 \\
Constant & -2.023 & 3.473 & 0.339 & 1 & 0.560 & 0.132 \\
\hline
\end{tabular}

Elevation = reference category; low $=1(<67 \mathrm{~m})$, high $=2(>67 \mathrm{~m})$.

Slope $=$ reference category; low $=1(<8)$, high $=2(>8)$.

Distance to $R F=$ reference category; low $=1(<1785 \mathrm{~m})$, high $=2(>1785 \mathrm{~m})$.

Presence of areca nut plantation $=1$; Absence $=0$.

Presence of rubber plantation $=1$; Absence $=0$.

Presence of coconut plantation $=1$; Absence $=0$.

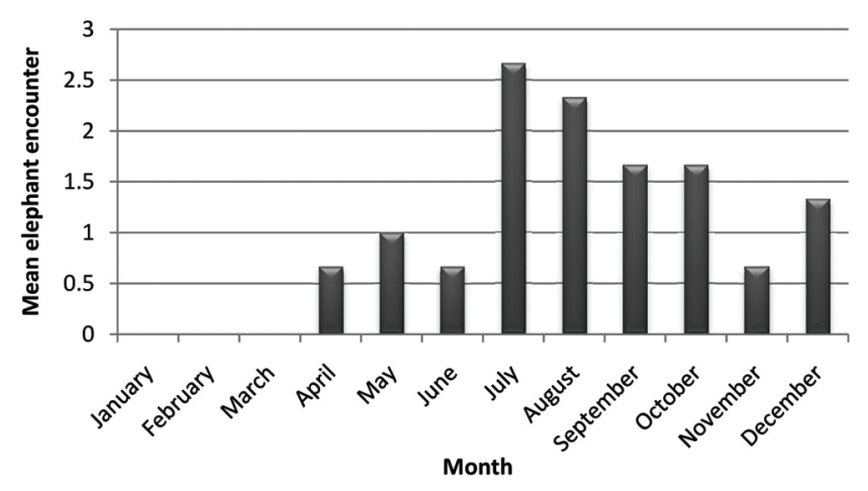

Figure 3. Crop damage during different months (2013-15).

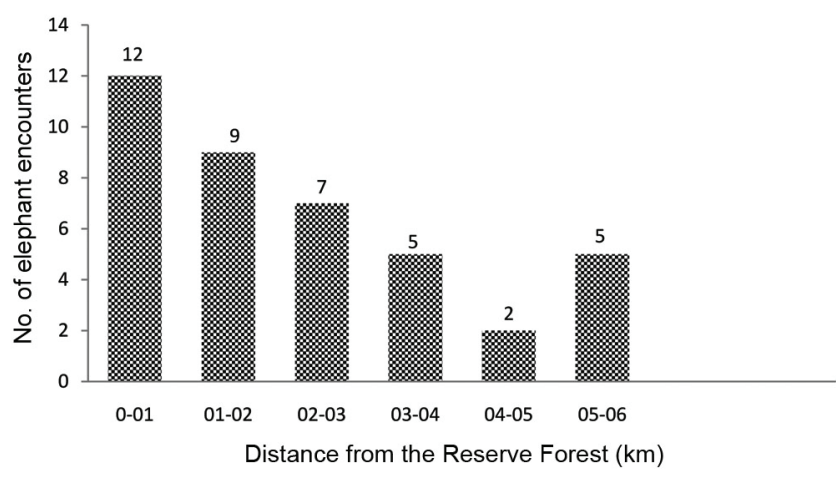

Figure 4. Effect of distance from the Reserve Forest on crop damage.

$(9.71 \%)$, coconut $(3.29 \%)$, teak $(1.09 \%)$, jackfruit $(0.14 \%)$ and mango $(0.04 \%)$ trees $(n=2109)$ (Figure 2$)$. Ninety per cent of the areca nut palms were uprooted in the productive phase and the remaining 9.79\% was trampled during the immature phase $(n=190)$. Coconut trees were uprooted predominantly $(95.89 \%)$ during the productive phase and the fresh leaves were consumed $(n=73)$.

The potential loss of Rs 5,076,827 (US\$ 72,948) per annum (Rs 2,217,363 (US\$ 31,861) (other crops) + Rs
$2,859,464$ (US\$ 41,087) (rubber)) by the Asian elephants was estimated in the district (Table 6).

\section{Damage to rubber trees}

The Asian elephants destroyed rubber trees worth Rs $2,859,464$ (US\$ 41,087) per annum from 0.8 ha in the two forest ranges of Nilambur South Forest Division (Figure 5). On seven occasions, the elephants fed on the bark of the rubber trees in the primary productive stage (from focus group discussions and field visits).

Three hundred and sixty-eight rubber trees out of 674 total damaged trees were in the primary productive stage (7-19 years of age), showing increased risk to rubber farmers in terms of economic loss (Table 7). Majority of the rubber trees were damaged while the elephants were moving towards the palatable crop species like paddy, plantain and pineapple through these plantations. Pineapple cultivation within the rubber estates close to the Reserve Forest was one of the main attractions for the elephants $(n=5)$.

\section{Discussion and conclusion}

In contradiction to the general belief prevailing in the area that elephants come out of the Reserve Forest during summer season due to scarcity of food and water, our results show that the highest crop damage occurred during the monsoon season (June-September). Seasonal encounter of the elephants showed a positive correlation with rainfall $(P=0.046$, Pearson's correlation coefficient, $r=0.584)$ in the study area. The elephant encounters were high during monsoon, as they were attracted towards the highly palatable mature crops. This observation is supported by previous studies from Asia and Africa ${ }^{2,22,23}$.

Plantain contributed to more than $50 \%$ of the total crops damaged by the Asian elephants, even though it is guarded by the farmers in most of the forest edges, which 
Table 6. Economic loss due to Asian elephants in Malappuram district

\begin{tabular}{lccccc}
\hline & Loss of coconuts/ & Loss of areca & Loss of rubber/annum & \multicolumn{2}{c}{ Loss of plantains/annum (Rs) } \\
\cline { 5 - 6 } Forest range & annum (Rs) & nut/annum (Rs) & $(\mathrm{Rs})$ & Nendra & Palayamthodan \\
\hline Kalikavu & $313,095.33$ & $645,788.80$ & $1,477,889.50$ & $27,624.75$ & $4,134.40$ \\
Karulai & $259,097.00$ & $695,905.00$ & $7,100,505.00$ & $27,256.42$ & $6,092.80$ \\
Vazhikadavu & $107,946.67$ & $44,534.40$ & - & $59,792.24$ & $8,921.60$ \\
Edavanna & $16,192.00$ & - & - & 982.21 & - \\
\hline
\end{tabular}

Table 7. Rubber trees damaged by Asian elephants in Nilambur South Forest Division in Malapparum district

\begin{tabular}{|c|c|c|c|c|}
\hline \multirow[b]{2}{*}{ Forest range } & \multirow{2}{*}{$\begin{array}{c}\text { Total number of rubber } \\
\text { trees damaged }\end{array}$} & \multirow{2}{*}{$\begin{array}{c}\text { Immature } \\
\text { phase }(0-6)\end{array}$} & \multicolumn{2}{|c|}{ Productive phase } \\
\hline & & & Primary stage (7-19) & Secondary stage (20-32) \\
\hline Karulai & 526 & 180 & 304 & 42 \\
\hline Kalikavu & 148 & 77 & 64 & 7 \\
\hline
\end{tabular}

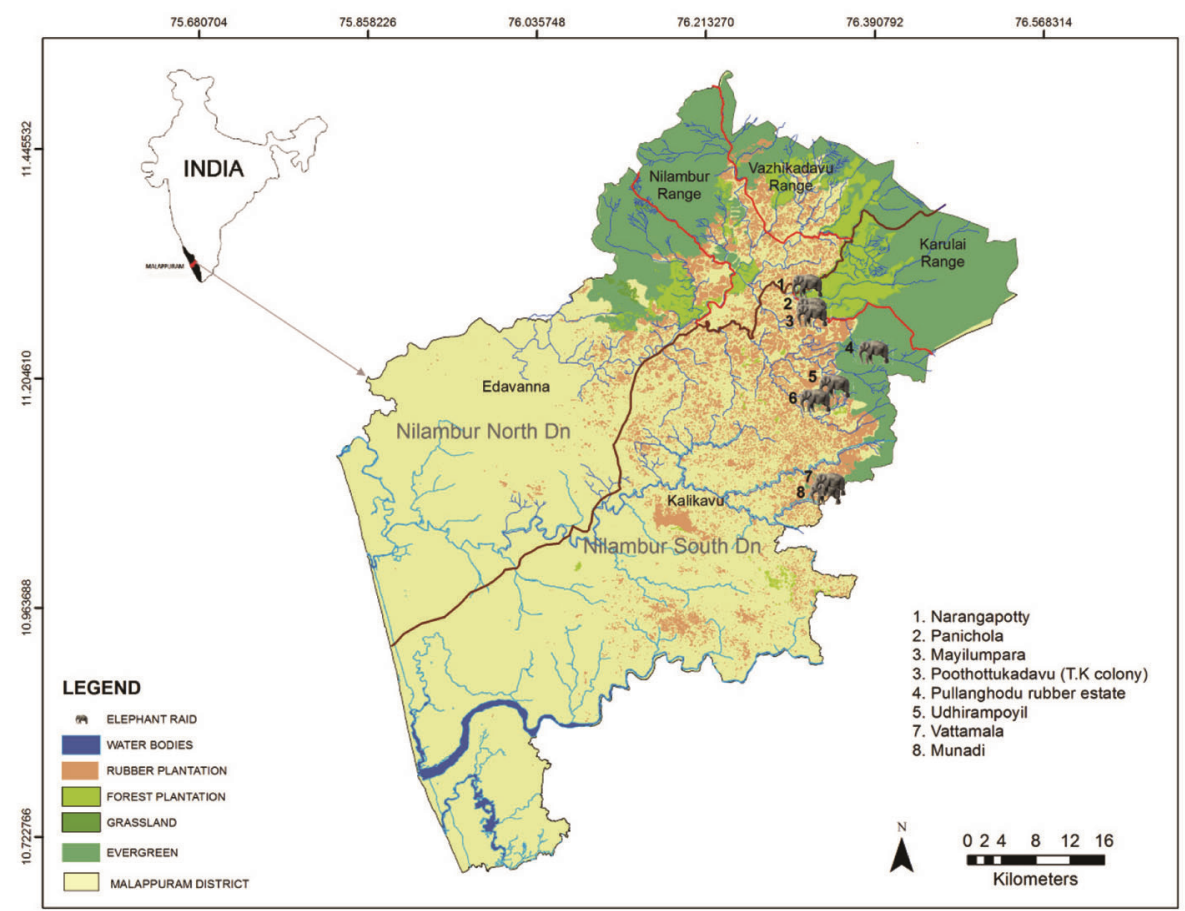

Figure 5. Locations of rubber trees damaged by Asian elephants.

was recognized as a major attractive crop in many other studies $^{7,15,24}$. The price of banana reached the highest during August (Rs $37.33 \pm 7.57$ per kg) and September (Rs $39 \pm 12.17$ per kg; source: Farm Information Bureau, Kerala). This is because of the Onam festival season in Kerala. Most of the farmlands were filled with mature plantain during this season due to the high market value for the fruit, and this was in turn attracting the elephants towards the croplands. This result is in agreement with the finding of Sukumar ${ }^{25}$, that the elephants forage on cultivated crops which have additional nutritive value than wild crops.

As most of the studies in other countries addressing HEC are based on visual assessment, this allows us to compare the economic losses in these countries $8,15,26,27$ We estimated potential economic loss of Rs 5,076,827 (US\$ 72,948) per annum from 3.58 ha of Malappuram district as crop loss due to Asian elephants, which was significantly higher compared to that of Thrissur district (Rs $1,735,625$ per annum) near the study area ${ }^{15}$. The difference is mainly because of the damage to rubber trees in Malappuram district, which was not reported in Thrissur district. The economic loss suffered by marginal farmers in the Nilambur part of Nilambur Elephant Reserve evokes a negative attitude against conservation of this endangered mammal among them, leading to a retaliatory response. According to observations in the field and also data collected from the Kerala Forest and 
Wildlife Department, 46 Asian elephants were found dead during the study period in the Nilambur Forest Divisions. Sixty-six per cent of the carcasses were found in and around the croplands close to Reserve Forest, which may be due to retaliatory action from the local people. The cost of crop damage estimated in this study will justify the need of investment in the forest fringe villages of Nilambur area by the Government authorities to formulate management strategies and effective mitigation measures which are essential for the conservation of the Asian elephants and to help the forest fringe farmers.

According to Chen et al. ${ }^{28}$, the average age of rubber trees prone to damage by elephant encounters was 2.9 years. In the present study, $54 \%$ of the rubber trees were damaged in their primary productive stage (7-19 years of age). Instead of the incidental damage here, the elephants attempted to feed on the rubber bark, preferably in this stage. Pineapple cultivation within the rubber plantations was one of the main attractants for the elephants. The central rachis of the palms and pineapple were the preferred food items for elephants ${ }^{29}$. The farmers from two of the five locations stopped pineapple cultivation in the rubber plantations due to frequent encounters with elephants within the estates. Farmers are least tolerant to the damage of high-value cash crops $^{30}$. Areca nut cultivation and distance from the Reserve Forest were the two predictable variables included in the model that influence crop-raiding by Asian elephants in Malappuram district. The intercropping of plantain with areca nut plantations was observed in some areas in the district that may be an added reason for the attraction towards areca nut. The distance from Reserve Forest identified as one of the predictive factors in this study was consistent with other stu$\operatorname{dies}^{4,5}$. Therefore, cultivation of highly attractive crops like areca nut and plantain should be avoided in the proximity of the Reserve Forest. The rubber trees cannot be considered as the preferred food item for the elephants as only $20 \%$ of them were damaged by feeding.

The actions taken by Kerala Forest and Wildlife Department along with the help of local people and NGOs to prevent the elephants from entering the croplands should be strengthened during the monsoon season and must focus on the areas of areca nut cultivation. It is important to discourage the intercropping of plantain with areca nut plantations at least within $6 \mathrm{~km}$ distance from the Reserve Forest. Stopping pineapple cultivation in the rubber plantations is a must to reduce the damage to the highly demanded rubber trees. Most of the forest fringes in Malappuram district are planted with rubber in which there is no human activity after the early morning hours of rubber tapping. Apart from the damage caused to rubber trees by the Asian elephants, they acted as a secondary shelter for the elephant herds. The intrusion of elephants up to $6 \mathrm{~km}$ away from the Reserve Forest was due to the presence of vast areas of rubber plantation sharing the boundary with the Forest, which give enough protection for the movement of the elephants to reach the nearby croplands without being noticed by the people. Proper monitoring strategy should be applied in the rubber plantations in the identified areas of frequent elephant intrusions to reduce such encounters.

1. Williams, C. et al., Elephas maximus. The IUCN Red List of Threatened Species, 2020, e.T7140A45818198; https://dx.doi.org/ 10.2305/IUCN.UK.2020-3.RLTS.T7140A45818198.en

2. Sukumar, R., Ecology of the Asian elephant in southern India: II. Feeding habits and crop raiding pattern. J. Trop. Ecol., 1990, 6, 33-53.

3. Chiyo, P. I., Cochrane, E. P., Naughton, L. and Basuta, G. I., Temporal patterns of crop raiding by elephants: a response to changes in forage quality or crop availability? Afr. J. Ecol., 2005, $43(1), 48-55$.

4. Prasad, G., Shiny, R., Reghunath, R. and Prasannakumar, V., A GIS-based spatial prediction model for human-elephant conflicts (HEC). Wildl. Biol. Pract., 2011, 7, 30-40.

5. Chen, Y., Marino, J., Chen, Y., Tao, Q., Sullivan, C. D., Shi, K. and Macdonald, D. W., Predicting hotspots of human-elephant conflict to inform mitigation strategies in Xishuangbanna, Southwest China. PLoS ONE, 2016, 11, 1-15.

6. Pozo, R. A., Coulson, T., McCulloch, G., Stronza, A. L. and Songhurst, A. C., Determining baselines for human-elephant conflict: a matter of time. PLOS ONE, 2017, 12, 1-17.

7. Saaban, S., Othman, N. B., Yasak, M. N. B., Nor, B. M., Zafii, A. and Compose-Arceiz, A., Current status of Asian elephants in Peninsular Malaysia. Gajah, 2011, 35, 67-75.

8. Zhang, L. and Wang, N., An initial study on habitat conservation of Asian elephant (Elephas maximus), with a focus on humanelephant conflict in Simao, China. Biol. Conserv., 2003, 112, 453459.

9. Karanth, K. K., Gopalaswamy, A. M., Prasad, P. K. and Dasgupta, S., Patterns of human-wildlife conflicts and compensation: insights from Western Ghats protected areas. Biol. Conserv., 2013, 166, 175-185.

10. Nath, N. K., Dutta, S. K., Das, J. P. and Lahkar, B. P., A quantification of damage and assessment of economic loss due to crop raiding by Asian elephant Elephas maximus (Mammalia: Proboscidea: Elephantidae): a case study of Manas National Park, Assam, India. J. Threat. Taxa, 2015, 7(2), 6853-6863.

11. Venkataramana, G. V., Sreenivasa and Lingaraju, H. G., An assessment of crop damage and economic loss caused by elephants in Harohalli and Kodihalli Ranges of Bannerghatta National Park, Karnataka, India. Curr. Sci., 2017, 113, 161-167.

12. Veeramani, A., Easa, P. S. and Jayson, E. A., Socio-economic status of cultivators and their interface with wild animals: a case study of Marayur Forest Range, Kerala. Indian For., 2004, 130, 513-520.

13. Easa, P. S. and Sankar, S., Study on man-wildlife interaction in Wayanad Wildlife Sanctuary, Kerala. KFRI Research Report No. 166, 2001, pp. 1-190.

14. Jayson, E. A. and Christopher, G., Human-elephant conflict in the southern Western Ghats: a case study from Peppara Wildlife Sanctuary, Kerala, India. Indian For., 2008, 134(10), 1309-1325.

15. Govind, S. K. and Jayson, E. A., Economic loss to the farmers due to wild animals in Thrissur district, Kerala, India. In Proceedings of the National Conference on Modern Trends in Zoological Research, Department of Zoology, St Aloysius College, Elthuruth, 2014, pp. 220-223.

16. Gureja, N., Menon, V., Sarkar, P. and Kyarong, S., Ganesh to bin Laden: human-elephant conflict in Sonitpur district of Assam. Occasional Report No. 6, Wildlife Trust of India, New Delhi, 2002, p. 45 . 
17. Rohini, C. K., Aravindan, T., Das, K. S. A. and Vinayan, P. A., People's attitude towards wild elephants, forest conservation and human-elephant conflict in Nilambur, southern Western Ghats of Kerala, India. J. Threat. Taxa, 2018, 10(6), 11710-11716.

18. Champion, H. G. and Seth, S. K., A Revised Survey of the Forest Type of India, Manager of Publications, New Delhi, 1968, p. 397.

19. Sreenath, G., Ground water information booklet of Malappuram district. Technical Report, Government of Kerala, India, 2013, pp. $1-4$.

20. Jayson, E. A., Studies on crop damage by wild animals in Kerala and evaluation of control measures. KFRI Research Report No. 169, 1999, p. 48.

21. Sitati, N. W., Walpole, M. J., Smith, R. J. and Leader-Williams, N., Predicting spatial aspects of human-wildlife conflict. J. Appl. Ecol., 2003, 40, 667.

22. Compose-Arceiz, A., Takatsuki, S., Ekanayaka, S. K. K. and Hasegawa, T., The human-elephant conflict in southeastern Sri Lanka: type of damage, seasonal patterns, and sexual differences in the raiding behaviour of elephants. Gajah, 2009, 31, 5-14.

23. Bhima, R., Elephant status and conflict with humans on the western bank of Liwonde National Park, Malawi. Pachyderm, 1998, 25, 74-80.

24. Ekanayaka, S. K. K., Compose-Arceiz, A., Rupasinghe, M., Pastorini, J. and Fernando, P., Patterns of crop raiding by Asian elephants in a human-dominated landscape in south-eastern Sri Lanka. Gajah, 2011, 34, 20-25.

25. Sukumar, R., The management of large mammals in relation to male strategies and conflict with people. Biol. Conserv., 1991, 55, 93-102.
26. Monroe, M. W. and England, L. D., Elephants and agriculture in Malaysia, Kuala Lumpur. Department of Wildlife and National Parks, Malaysia, 1978.

27. Salman, S. and Nasharuddin, O., A preliminary study on disturbance cases by elephants (Elephas maximus) in the state of Johor. J. Wildl. Parks, 2003, 21, 1-11.

28. Chen, S., Yi, Z. F., Arceiz, A. C., Chen, M. Y. and Webb, E. L., Developing a spatially explicit, sustainable and risk-based insurance scheme to mitigate human-wildlife conflict. Biol. Conserv., 2013, 168, 31-39.

29. Jayson, E. A., Studies on man-wildlife conflict in Peppara Wildlife Sanctuary and adjacent areas. KFRI Research Report No. 140, 1998, pp. 1-71.

30. Messmer, T. A., The emergence of human-wildlife conflict management: turning challenges into opportunities. Int. Biodeteriora. Biodegrad., 2000, 45, 97-102.

ACKNOWLEDGEMENTS. We thank the Kerala Forest Research Institute, Peechi for providing financial support. We also thank the forest fringe farmers and forest officials of Malappuram district, Kerala for their cooperation and support during the fieldwork. We would like to extend our gratitude to Dr Suresh K. Govind for his support during data analysis.

Received 26 June 2018; revised accepted 25 June 2021

doi: $10.18520 / \mathrm{cs} / \mathrm{v} 121 / \mathrm{i} 4 / 521-528$ 